William \& Mary Law School

William \& Mary Law School Scholarship Repository

\title{
The Race to the Top to Reduce Prosecutorial Misconduct
}

Adam M. Gershowitz

William \& Mary Law School, amgershowitz@wm.edu

Follow this and additional works at: https://scholarship.law.wm.edu/facpubs

Part of the Courts Commons, Criminal Procedure Commons, Judges Commons, and the Legal Ethics and Professional Responsibility Commons

\section{Repository Citation}

Gershowitz, Adam M., "The Race to the Top to Reduce Prosecutorial Misconduct" (2021). Faculty Publications. 2027.

https://scholarship.law.wm.edu/facpubs/2027

Copyright c 2021 by the authors. This article is brought to you by the William \& Mary Law School Scholarship Repository.

https://scholarship.law.wm.edu/facpubs 


\title{
THE RACE TO THE TOP TO REDUCE PROSECUTORIAL MISCONDUCT
}

\author{
Adam M. Gershowitz*
}

This Essay offers an unconventional approach to detering prosecutorial misconduct. Trial judges should use their inherent authority to forbid prosecutors from appearing and handling cases in their courtrooms until the prosecutors have completed training on Brady v. Maryland, Batson v. Kentucky, and other types of prosecutorial misconduct. If a single trial judge in a medium-sized or large jurisdiction imposes training prerequisites on prosecutors, it could set off a race to the top that encourages other judges to adopt similar (or perhaps even more rigorous) training requirements. A mandate that prosecutors receive ethics training before handling any cases is comparable to the enhanced training requirements that some state legislatures impose on indigent defense lawyers. This Essay argues that trial judges arguably have the inherent authority to impose a training requirement on prosecutors to ensure the orderly administration of justice.

\section{INTRODUCTION}

Prosecutorial misconduct is a serious problem in the United States. Unfortunately, the two main mechanisms to deal with the problem-lawyer disciplinary boards and adjudicatory remedies - have not been up to the task. State ethics boards rarely discipline prosecutors ${ }^{1}$ and courts rarely reverse convictions for prosecutorial misconduct.

In recent years, scholars have suggested that there is a greater role for courts to play in regulating lawyers. ${ }^{2}$ That focus has primarily been on state

\footnotetext{
* R. Hugh \& Nolie Haynes Professor of Law, William \& Mary Law School. This Essay was prepared for the Colloquium entitled The Judicial Role in Professional Regulation, hosted by the Fordham Law Review and the Stein Center for Law and Ethics on October 9, 2020, at Fordham University School of Law. My thanks to Bruce A. Green for inviting me to participate in the Colloquium and to the participants for helpful suggestions. I am also grateful to my colleague Alan Meese for discussions about the race to the top in corporate law and to Abby Boettiger and Karly Newcomb for excellent research assistance.
}

1. See Bruce A. Green, Prosecutorial Ethics in Retrospect, 30 GeO. J. Legal ETHICS 461, $478-79$ (2017).

2. See Bruce A. Green \& Samuel J. Levine, Disciplinary Regulation of Prosecutors as a Remedy for Abuses of Prosecutorial Discretion: A Descriptive and Normative Analysis, 14 OHIO ST. J. CRIM. L. 143, 148 (2016) (examining whether "state courts, through rule making or interpretation, [can] adopt independent ethical standards to govern prosecutors' exercise of charging discretion and sanction prosecutors for abuses of discretion that contravene the 
supreme courts and ethics standards. This Essay suggests that effective regulation of prosecutors can come from a less prestigious set of judges and a less formal set of regulations.

Trial judges - the judges who see prosecutors in their courtrooms day in, day out-should impose minimum training requirements on prosecutors in order for them to appear as counsel to litigate cases in their courtrooms. Until prosecutors have completed satisfactory training on topics such as Brady $v$. Maryland, 3 Batson v. Kentucky, 4 and improper argument, judges should simply refuse to allow the prosecutors to handle cases in their courtrooms. No formal policy ruling is necessary from a state supreme court. No ethics code need be drafted, debated, or interpreted.

If a judge demands adequate training before prosecutors can handle cases in her courtroom, the district attorney's office will then have two options to comply: (1) shift better-trained prosecutors (who already have completed the judge's training requirements) into that judge's courtroom or (2) provide the necessary training to more of the office's prosecutors. ${ }^{5}$

Option one, to shift better-trained prosecutors, would be cheaper and easier, but it will likely upset the other judges in the courthouse who would lose the services of the better-trained prosecutors who had been practicing in their courtrooms. Judges are competitive and territorial and thus strongly resistant to being left with what they may see as an inferior group of lawyers compared to the lawyers practicing in front of another judge in the courthouse. ${ }^{6}$ Moreover, all judges seemingly oppose prosecutorial misconduct and should want to take the same steps as their colleagues to prevent it. And, of course, judges are strongly averse to being reversed on appeal, 7 especially when their colleagues down the hall might be reversed less often.

If judges oppose prosecutorial misconduct, hate being reversed, and do not like being left with less qualified lawyers, what will they do when a colleague imposes training prerequisites that capture the better-trained prosecutors? Most likely, the other trial judges will insist on the same (or better) training and competency than the first-mover judge down the hall.

The best analogy to this cascade of events is the "race to the top" that has long been a fixture in corporate law scholarship. The race to the top theory provides that when states compete, they develop their law in a way that is

applicable rules"). See generally Samuel J. Levine, Disciplinary Regulation of Prosecutorial Discretion: What Would a Rule Look Like?, 16 OHIO ST. J. CRIM. L. 347 (2019).

3. 373 U.S. 83 (1963)

4. 476 U.S. 79 (1986)

5. The district attorney's office could also challenge the legality of the trial court's training order. As discussed in Part IV, infra, the legality of such an order is unclear.

6. Federal judges are similarly competitive in their efforts to hire the "best" law clerks. See Christopher Avery et al., The New Market for Federal Judicial Law Clerks, 74 U. CHI. L. REV. 447, 453 (2007).

7. See Joseph L. Smith, Patterns and Consequences of Judicial Reversals: Theoretical Considerations and Data from a District Court, 27 JUST. SYS. J. 28, 30-33 (2006). 
better for shareholders and thus more optimal for the firms themselves. ${ }^{8}$ In short, competition promotes better rulemaking and more optimal results.

There has been almost no discussion of a race to the top in criminal justice or legal ethics scholarship. ${ }^{9}$ Nor does there appear to be competition between judges to capture the best prosecutors or reduce prosecutorial misconduct. At present, judges wear the robes, but they do not call the shots about which prosecutors practice in their courtrooms and how prepared those prosecutors must be to avoid misconduct. District attorneys' offices file criminal charges and the top management of the offices send whichever prosecutors they want into the judges' courtrooms. ${ }^{10}$

Yet, the playing field is ripe for trial judges to turn the tables and insist on minimum prosecutorial training and to trigger a race to the top. Judges are the masters of their courtrooms. They control when court starts, when it stops, and nearly every other official decision that happens in between. Judges have inherent authority to set a minimum dress code, to hold lawyers in contempt, to discipline counsel, and to deny pro hac vice motions. This Essay goes a step further and argues that trial judges' inherent authority should extend to requiring that prosecutors complete a minimum amount of training to avoid Brady, Batson, and improper argument.

I sketch the argument by breaking it down into four parts. Part I explains the current system in which the district attorney's office assigns prosecutors to courtrooms. Part I also describes how judges presently exert no authority over the training of the prosecutors in their courtrooms. Finally, Part I briefly explores how the current system allows for prosecutorial misconduct to occur by accident. Part II then reviews the race to the top theory and explains how it could apply in criminal courthouses-particularly in medium-sized and large jurisdictions-around the country. Part III explains that some states and counties have imposed minimum training standards but only on defense attorneys appointed to represent indigent defendants. Finally, Part IV considers the legal basis judges could invoke to impose training requirements on prosecutors.

8. See generally Charles Tiebout, A Pure Theory of Local Expenditure, 64 J. PoL. ECON. 416 (1956).

9. One scholar has made the argument that there is a "market for criminal justice that is driven by attempts to displace crime to neighboring communities" and that it implicates the race to the top or race to the bottom question. Doron Teichman, The Market for Criminal Justice: Federalism, Crime Control, and Jurisdictional Competition, 103 MiCH. L. REV. 1831, 1857-59 (2005). See generally Doron Teichman, Decentralizing Crime Control: The Political Economy Perspective, 104 MICH. L. REV. 1749 (2006) (responding to critics). This Essay addresses a different type of competition: a competition between judges sitting in the same jurisdiction.

10. Of course, trial judges sometimes become exasperated with particular prosecutors and they occasionally pressure the higher-ups in the district attorney's office to move a prosecutor to another courtroom. For the most part, however, it is the district attorney's office that controls which prosecutors go to which courtrooms. And it is the district attorney's office that typically decides how much training its lawyers must complete. 


\section{THE CURRENT RACE TO NOWHERE}

\section{A. Judges Do Not Pick Their Prosecutors}

With over 2300 prosecutors' offices across the country, 11 the method of assigning prosecutors to cases obviously varies. For purposes of this Essay, I want to put aside federal cases 12 and small-town prosecutions, which together account for only a modest portion of the nation's criminal cases. Instead, I wish to focus on the bulk of criminal prosecutions that take place in state courts in medium-sized and large jurisdictions. 13

Most jurisdictions have multiple judges-sometimes dozens of judgeswho handle criminal cases. In these jurisdictions, it is common for a prosecutor to be assigned to a particular courtroom for months at a time.14 The judge does not decide which prosecutors will practice in front of her. Rather, the top brass in the district attorney's office assign prosecutors to particular courtrooms. ${ }^{15}$ A prosecutor might spend a year in a felony court. If the prosecutor has been assigned to a demanding or difficult felony judge, the management of the district attorney's office may then give that prosecutor a break on the next assignment and place him in a lower-stress position-for

11. See Steven W. Perry, Bureau of Just. Stats., Bulletin: Prosecutors in State COURTS, 2005, at 2 (2006), https://www.bjs.gov/content/pub/pdf/psc05.pdf [https://perma.cc/ WF8L-XL3G].

12. In the federal system, it is common for the U.S. attorney to assign particular cases to prosecutors before indictment, long before the court clerk assigns a case to a particular district judge. See Brief of Plaintiff-Appellant at 24-25, United States v. Rodriguez, No. 19-20045 (5th Cir. June 28, 2019), 2019 WL 2745440 ("In the Southern District of Texas (like other federal districts), an AUSA often is assigned to an investigation long before criminal charges are filed. . . A district judge is assigned to a criminal case only after charges are filed." (citations omitted)). Each assistant U.S. attorney can therefore have cases in front of multiple judges in different courtrooms. Of course, while it is common for legal scholars to focus on the federal system, only a small percentage of criminal cases are federal. See William J. Stuntz, The Political Constitution of Criminal Justice, 119 HARV. L. REV. 781, 787 (2006) (describing the large number of state cases and noting that "[f]ederal law enforcement is, by comparison, small potatoes").

13. Nearly two million prosecutions in the United States originate out of just twenty-five of the largest prosecutors' offices. See Adam M. Gershowitz \& Laura R. Killinger, The State (Never) Rests: How Excessive Prosecutor Caseloads Harm Criminal Defendants, $105 \mathrm{Nw}$. U. L. REV. 261, 269 (2011).

14. See 1 Wayne R. LaFave et al., Criminal Procedure $\S 1.10$ (d) (4th ed. 2020) ("Under fairly common assignment systems that give trial judges long term assignments to the criminal division and prosecutor[s] and public defenders fairly long term assignments to the courtroom of a particular judge, the same handful of persons will be interacting with each other on a daily basis month after month."); Roberta K. Flowers, An Unholy Alliance: The Ex Parte Relationship Between the Judge and the Prosecutor, 79 NEB. L. REv. 251, 269 (2000) ("Additionally, prosecutors appear daily in front of the same judge. The prosecutor's duties typically involve frequent official contact with the court. In many jurisdictions, the prosecutor's case assignments may be based on the courtroom in which the case is being handled. A group of prosecutors may be assigned to one judge and appear in court on every matter that is assigned to that judge's courtroom." (footnotes omitted)); Aditi Sherikar, Note, Prosecuting Prosecutors: A Need for Uniform Sanctions, 25 Geo. J. Legal ETHICS 1011, 1021 (2012) ("[O]ften, prosecutors are assigned to a specific judge ....").

15. See Gershowitz \& Killinger, supra note 13, at 271 (describing the assignment of three prosecutors to each felony court in Harris County, Texas). 
instance, the misdemeanor division-for a few months, before reassigning him to a more onerous role in another courtroom. 16

On rare occasions, judges become extremely upset with particular prosecutors and ban them from their courtrooms. ${ }^{17}$ In other cases - it is hard to know how often - judges likely complain to the top management of the district attorney's office and pressure them to reassign a prosecutor to a different court. But these cases are the exception that proves the rule. The key point is that the management of the district attorney's office decides which prosecutors will be assigned to which courtrooms.

\section{B. The Problem of Prosecutorial Misconduct}

With millions of criminal prosecutions per year and about 25,000 prosecutors in the United States, 18 there is ample opportunity for prosecutorial misconduct. Some of this misconduct is the result of prosecutors purposefully withholding favorable evidence or intentionally striking jurors based on their race. It is difficult to stop prosecutors who are intent on flouting the rules.

But much prosecutorial misconduct is accidental, and therefore, there is a chance to prevent it through increased training and awareness. ${ }^{19}$ For example, the most common type of prosecutorial misconduct is a Brady violation in which prosecutors fail to turn over favorable evidence to the defense. ${ }^{20}$ Some Brady violations are accidental. For instance, imagine that a domestic violence victim initially tells police officers that she was injured by falling, not because she was hit by her partner. The police officers do not believe the victim's initial story and after continued interviewing, the victim eventually tells the officers that she was in fact abused. Strongly believing the victim's initial story to be untrue (and lacking detailed training on how to spot Brady evidence), the prosecutor might fail to turn the initial statement over to the defense. ${ }^{21}$ In other words, because the prosecutor does not believe the initial story about falling down, he might not realize he is dealing with Brady material. And because the Brady doctrine does not turn on the

16. See, e.g., Murray Newman, Piling On, Life at the Harris CNTy. Crim. Just. Ctr. (Aug. 10, 2010, 11:27 AM), https://harriscountycriminaljustice.blogspot.com/2010/08/pilingon.html [https://perma.cc/V2VS-X3WV].

17. See, e.g., Gabrielle Banks \& Lise Olsen, Houston Federal Judge Bars Female Prosecutor from Trial, Sparking Stand-off with U.S. Attorney's Office, Hous. CHRON. (Feb. 13, 2019, 10:35 AM), https://www.houstonchronicle.com/news/houston-texas/houston/ article/Houston-federal-judge-bars-female-prosecutor-from-13610959.php\#: : text $=\mathrm{A} \%$ 20 federal $\% 20$ judge $\% 20$ banished $\% 20$ a,U.S. $\% 20$ District $\% 20 J u d g e \% 20$ Lynn $\% 20 \mathrm{~N}$ [https://perma.cc/5B2W-S5CA].

18. See Jeffrey Bellin, The Power of Prosecutors, 94 N.Y.U. L. REV. 171, 207 (2019).

19. See Adam M. Gershowitz, The Challenge of Convincing Ethical Prosecutors That Their Profession Has a Brady Problem, 16 OHIO ST. J. CRIM. L. 307, 311-12 (2019).

20. See Brady v. Maryland, 373 U.S. 83, 87 (1963).

21. See Gershowitz, supra note 19, at 311-12; see also United States v. Brooks, 367 F.3d 1128,1137 (9th Cir. 2004) (discussing the prevalence of domestic violence victims initially denying they have been assaulted). 
prosecutor's good faith, the prosecutor's actions may constitute reversible error.

While future prosecutors take criminal procedure classes in law school, 22 additional training and office-wide examination of prior mistakes is important to keep them from committing Brady violations and other misconduct. 23 Perhaps supervising prosecutors have long been providing the robust training necessary to avoid misconduct. ${ }^{24}$ And perhaps the new progressive prosecutor movement has enhanced the amount of training prosecutors' offices provide their lawyers. ${ }^{25}$ But many experts are skeptical. ${ }^{26}$ Prosecutors are overburdened with huge caseloads. ${ }^{27}$ Good training, especially if it involves travel to conferences, is expensive and, with limited budgets, it is hard for offices to ensure that all of their prosecutors receive the training they need. 28

Additionally, some offices may not believe their prosecutors need extensive training to avoid misconduct. ${ }^{29}$ Some elected district attorneys are primarily interested in holding onto their jobs (or improving their chances for higher office $)^{30}$ rather than in the professional development of their line attorneys. Even ethical prosecutors who are trying to follow best practices

22. Law schools do not do a particularly good job of teaching future prosecutors to avoid misconduct. Most students do not take the "bail to jail" criminal adjudication course, where Brady is covered. For those who do take the course, the Brady doctrine typically occupies only a portion of one class session. And during that class session, students primarily learn about U.S. Supreme Court case law that neatly packages the Brady violation in a judicial decision, instead of the much more difficult task of how to spot Brady problems and make decisions about disclosure.

23. See Bruce A. Green, Beyond Training Prosecutors About Their Disclosure Obligations: Can Prosecutors' Offices Learn from Their Lawyers' Mistakes?, 31 CARDOzO L. REV. 2161,2161 (2010).

24. Model Rule of Professional Conduct 5.1(b) provides that "[a] lawyer having direct supervisory authority over another lawyer shall make reasonable efforts to ensure that the other lawyer conforms to the Rules of Professional Conduct." MODEL Rules OF PRo. CONDUCT r. 5.1(b) (AM. BAR ASS'N 2020).

25. See David A. Sklansky, The Progressive Prosecutor's Handbook, 50 U.C. DAVIS L. REV. ONLINE 25, 33-34 (2017) (identifying a generous disclosure policy with checklists for prosecutors as a key factor).

26. See, e.g., Daniel S. Medwed, The Zeal Deal: Prosecutorial Resistance to Postconviction Claims of Innocence, 84 B.U. L. REV. 125, 170-71 (2004) ("Incoming prosecutors may receive training and materials concerning their ethical duties, but these requirements are not emphasized as they work in the field over time.").

27. See Gershowitz \& Killinger, supra note 13 , at 268-70.

28. See Ronald F. Wright, Persistent Localism in the Prosecutor Services of North Carolina, 41 CRIME \& JUST. 211, 225-26 (2012) "District attorneys must request permission to spend money for training ADAs or support staff, and the budget allows for only a handful of prosecutors each year to attend training events out-of-state . ...").

29. See Connick v. Thompson, 563 U.S. 51, 96 (2011) (Ginsburg, J., dissenting) ("Connick's Office gave prosecutors no Brady guidance, and had installed no procedures to monitor Brady compliance.").

30. See, e.g., Laurie L. Levenson, The Politicization of Prosecutors: A Tribute to the Work of Bennett Gershman, 16 OHIO ST. J. CRIM. L. 325, 340 (2019) ("For years, prosecutors have actually used their jobs as stepping stones to higher office."). 
likely underestimate the extent of the prosecutorial misconduct problem because they are susceptible to in-group bias. ${ }^{31}$

The legal system has developed multiple avenues to deal with the problem of prosecutorial misconduct. Lawyers are subject to discipline by state ethics bodies. Appellate courts can reverse convictions. And appellate judges can go further by calling out prosecutors in their opinions and shaming them for misconduct. 32 These approaches are ex post however and have seemingly not had a substantial impact in reducing misconduct. ${ }^{33}$ An earlier intervention point might therefore be beneficial.

\section{The Race to the Top: Competition Among Trial JudGeS For the BEST-TRAINED PROSECUTORS}

How could judges act earlier to prevent prosecutorial misconduct? The answer, perhaps surprisingly, is that a trial court could impose minimum training standards for avoiding prosecutorial misconduct. Unless prosecutors complete that training, the judge would not allow them to handle cases in the judge's courtroom. By insisting on adequately trained prosecutors, the judge can create a race to the top that will lead more judges to demand the same (or better) training, which in turn will force district attorneys' offices to provide enhanced training to their prosecutors. This part describes how a single trial judge could cause that cascade and how it would resemble the race to the top theory prevalent in corporate law.

Let us start by imagining the court system in a large county. The county courthouse has twenty-two felony courts, fifteen misdemeanor courts, and three juvenile courts. ${ }^{34}$ The top management of the district attorney's office assigns three prosecutors - whichever three prosecutors the elected district attorney wishes - to each courtroom. This amounts to 120 line prosecutors assigned exclusively to specific courtrooms. As detailed in Part I.A above, judges ordinarily have no say over which prosecutors will be assigned to their courtrooms.

Now imagine that the trial judge in Felony Court 1 imposes a rule that no prosecutor can appear in her courtroom unless that prosecutor has had three hours of Brady training, including simulations, in the last two years. ${ }^{35}$ The

31. See Gershowitz, supra note 19 , at 307 .

32. See generally Lara Bazelon, For Shame: The Public Humiliation of Prosecutors by Judges to Correct Wrongful Convictions, 29 GEO. J. LEGAL ETHICS 305 (2016).

33. See generally Adam M. Gershowitz, Prosecutorial Shaming: Naming Attorneys to Reduce Prosecutorial Misconduct, 42 U.C. Davis L. REV. 1059 (2009).

34. This example is drawn from Harris County, Texas.

35. There are, of course, large and difficult questions of how the training would operate. For instance, what should be included in the training, who should design it, and who should administer it? There is some scholarly work on this topic. See, e.g., Bennett L. Gershman, Educating Prosecutors and Supreme Court Justices About Brady v. Mary land, 13 LOY. J. PUB. INT. L. 517, 521 (2012) (offering an example of a Brady training syllabus, along with problems prosecutors should have to study). The questions are thorny, however. If judges designed the training, it might improve their understanding of the law. On the other hand, the prosecutor's office has a greater understanding of the different policing agencies it interacts with and the 
three prosecutors currently assigned to Felony Court 1 do not meet this standard. Indeed, only a handful of prosecutors in the entire district attorney's office have completed such training in the last two years.

The district attorney's office has three choices in responding to the training order from the judge: (1) challenge the legality of the judge's training demand, (2) abandon the felony cases in Felony Court 1, or (3) move prosecutors who have completed the necessary training from their other assignments so that they can practice in Felony Court 1 . As explained in Part IV below, there are plausible reasons why the district attorney's office should lose a challenge to the trial judge's order. Option two is even less tenable because an elected district attorney cannot simply abandon serious felony charges against a large swath of the county's felony defendants. There is therefore a very good chance that the district attorney's office will choose option three and move the prosecutors who have completed the required training into Felony Court 1.

The three prosecutors being moved into Felony Court 1 have to come from somewhere else, of course. Imagine that those prosecutors had been stationed in Felony Courts 7, 8, and 9. How will the judges of those courts react? It is quite possible that the judges in Felony Courts 7, 8, and 9 will feel like they are losing out and that another judge is taking something from them. The natural reaction of the judges in Felony Courts 7, 8, and 9 may therefore be to impose the same training requirement as the judge in Felony Court 1.

If the judges in Felony Courts 7,8 , and 9 match the rule imposed by the judge in Felony Court 1, the district attorney's office will have a serious problem. Instead of having to come up with three prosecutors who meet the requisite ethics training, the district attorney's office now has to find twelve of its prosecutors who have completed the requisite training. And that assumes none of the other felony, misdemeanor, or juvenile court judges (a total of thirty-six other judges in this jurisdiction) follow suit and impose the same training requirement.

Perhaps there are many prosecutors who have gone out and completed additional training on prosecutorial misconduct in their spare time. But that is not likely. Instead, the more likely scenario is that the district attorney's office will have to provide extensive Brady training to a lot more of its prosecutors.

Of course, more training will not stop prosecutors who desire to intentionally flout the rules and engage in prosecutorial misconduct. But additional training that is repeated every few years will likely be beneficial to the type of prosecutors who commit the accidental misconduct described in Part I.B above. Therefore, judges competing amongst themselves for better-trained prosecutors leads to a better rule (more training) and hopefully a more optimal result (less prosecutorial misconduct).

gaps where police and prosecutors could drop the ball on Brady disclosures. Because of space constraints, I leave these challenging questions for future analysis. 
Moreover, it is possible that the improvement could go one step further. Imagine the same scenario above: the judge in Felony Court 1 adopted a minimum training requirement that resulted in prosecutors being reshuffled around the courthouse. This time, however, imagine that things did not end there. Let's say that the judge in Felony Court 2 decides he likes the idea of capturing the prosecutors who have been best trained to avoid Brady violations. The judge in Felony Court 2 therefore decides to impose an even more rigorous training requirement than the one initially imposed by the judge in Felony Court 1. Now the prosecutors will receive even more extensive training. Assuming we believe that more training is beneficial, this scenario begins to resemble the race to the top theory.

Corporate law scholars have long debated whether competition among states leads to more optimal outcomes for shareholders. Corporate managers can choose to incorporate in states where the law is more favorable to management, or they can incorporate in states where the law is more favorable to shareholders. One theory-the pessimistic one-is that the market for corporate law creates a race to the bottom in which states compete to have the best set of rules that are favorable to management. 36 Because management should be acting for the interest of shareholders, not themselves, seeking out legal regimes favorable to management is bad, hence the term "race to the bottom." The other school of thought- the optimistic one-is that market competition among states creates a race to the top in which management selects the states that have the best developed law that favors shareholders and thus the success of the firm. ${ }^{37}$ Put differently, so long as there are a sufficient number of states and so long as such states internalize the full impact of the laws they promulgate, competition between such jurisdictions will result in optimal laws - a race to the top.

The race to the top literature is mostly absent from the criminal justice world. ${ }^{38}$ And for good reason. States do not really compete with each other when designing their criminal laws and procedural rules. Nor do states have to internalize the full cost of the rules they adopt because prosecutors can exercise prosecutorial discretion to ignore or minimize the effects of some laws and because appellate courts can rely on doctrines like harmless error to eliminate the benefit of procedural protections.

Nor is the race to the top theory a perfect fit for the concept of judges competing for prosecutors, as described above. But it is also not a terrible analogy either. Think of judges as the states (like Delaware, for instance). Then think of the prosecutors as firms that the judges are competing for. Finally, think of the judges' rules about minimum prosecutorial training as the governing legal regimes (like a states' corporate law). Put simply, judges (the states) are designing a legal regime (training rules) that will attract the

36. See William L. Cary, Federalism and Corporate Law: Reflections upon Delaware, 83 YALE L.J. 663, 705 (1974).

37. See Ralph K. Winter Jr., State Law, Shareholder Protection, and the Theory of the Corporation, 6 J. LeGAL STUD. 251, 254-62 (1977).

38. See supra note 9 and accompanying text. 
best prosecutors (the firms). To complete the analogy, the citizens (the shareholders) benefit by having better-trained prosecutors and hence, less prosecutorial misconduct.

The analogy is of course imperfect. The line prosecutors are not choosing the judges they will appear in front of. Nor are the judges internalizing the full costs of the training rules they have promulgated. Those costs are instead pushed off on the district attorney's office, which must train (or pay for someone else to train) the prosecutors.

My point is not to suggest that competition among judges for the besttrained prosecutors perfectly matches the race to the top theory developed in corporate law. Instead, my point is to think about the race to the top idea in the big picture. When a judge imposes a training requirement, it can set off market competition with other judges and a chain of events that will result in more optimal training for all prosecutors. In a big picture sense, this is a race to the top in which a single judge operating in a larger system can trigger improved outcomes for the criminal justice system at large.

\section{Training STANDARdS For Defense ATtORnEys}

The idea that lawyers must complete adequate training before they can begin handling important cases is not novel. Indeed, it is not even novel in the criminal law world. In some jurisdictions, criminal defense lawyers must meet requirements, beyond what is ordinarily required to practice law, to represent indigent defendants. Appointed lawyers must complete more training than civil lawyers and privately retained criminal defense lawyers before they can handle appointed cases. These enhanced standards-which primarily come from legislatures - provide a model for imposing additional training requirements on prosecutors.

Texas is a good example of a state that imposes additional requirements on appointed lawyers. For many years, some Texas judges had free rein to appoint whoever they wanted to-including unqualified lawyers-to represent indigent defendants. ${ }^{39}$ In 2001, the Texas legislature passed the Fair Defense Act, ${ }^{40}$ which requires that counties "adopt and publish written countywide procedures for timely and fairly appointing counsel for an indigent defendant" and to "ensure that appointments are allocated among qualified attorneys in a manner that is fair, neutral, and nondiscriminatory." 41

In implementing this requirement, Harris County, Texas, (home to the state's largest criminal justice system) requires attorneys to attend ten hours of continuing legal education (CLE) each year, including one hour of ethics instruction, before they can be appointed to represent indigent defendants. Harris County also requires that appointed lawyers "agree to attend CLE programs as directed by the Presiding Judge."42 Smaller counties in Texas

39. See Jennifer Laurin, Gideon by the Numbers: The Emergence of Evidence-Based Practice in Indigent Defense, 12 OHIо ST. J. CRIM. L. 325, 343-44 (2015).

40. ch. 906, 2001 Tex. Gen. Laws 1800.

41. TeX. Code Crim Proc. AnN. art. 26.04(a), (b)(6) (West 2020).

42. See Harris CnTy. Crim. Cts. Local R. 24.5.1.7. 
have likewise imposed CLE requirements for criminal defense lawyers to qualify as appointed counsel. 43

Jurisdictions in other states have also required advanced training for appointed defense lawyers before they can be appointed to represent indigent defendants. For instance, lawyers in Craven County, North Carolina, must have at least twelve hours of CLE credit specifically in the area of criminal jury trials in order to be appointed to handle serious felony cases. ${ }^{44}$ Other North Carolina counties have similar requirements. ${ }^{45}$ In adopting new standards, the executive director of North Carolina's Office of Indigent Defense Services explained that existing attorneys could remain on the list but that, "to the extent that there are continuing education requirements to remain on a list, all counsel will need to meet those training requirements." 46

New York's indigent defense commission also encourages its counties to require training before criminal defense lawyers can be assigned appointed cases. ${ }^{47}$ Other states, such as Ohio, have specific training requirements for defense attorneys appointed to handle capital cases. 48

There are surely more examples from across the country. My point is not to catalog the requirements imposed on court-appointed counsel, nor is it to suggest that CLE credit is an adequate solution to the myriad problems with indigent defense in the United States. Rather, these examples simply highlight that some legislatures and court systems have imposed minimum training requirements on appointed criminal defense attorneys beyond the minimum requirements for other attorneys. Put simply, in many courtrooms across the country, criminal defense lawyers cannot set foot inside a courtroom to defend indigent defendants unless they first complete minimum training requirements.

The examples above from Texas, North Carolina, New York, and Ohio might suggest that prosecutorial training requirements should come from state legislatures or statewide rules committees. Yet, it does not appear that

43. See Walker County Court Plan, WALKER CNTY. CT. ATL. (Sept. 25, 2017), http://tidc. tamu.edu/IDPlan/ViewPlan aspx?PlanID=276 [https://perma.cc/89LK-HKKK] (requiring six hours of CLE in criminal law and procedure per year).

44. See Craven Cnty. Bar Ass'n, Regulations for Appointment of Counsel in CASES Under the Indigent DeFense Services ACt 8 (2015), http://www.ncids.org/ IndigentApptPlans/Non-PD\%20Appt\%20Plans/CravenCounty.pdf [https://perma.cc/VY3SP3YU].

45. See Onslow Cnty. Bar, Regulations for Appointment of Counsel in Cases UNDER INDIGENT DEFENSE SERVICES ACT 8 (2015), http://www.ncids.org/ IndigentApptPlans/Non-PD\%20Appt\%20Plans/OnslowCounty.pdf [https://perma.cc/NS39MZMF].

46. Memorandum from Thomas K. Maher, Exec. Dir., Indigent Def. Servs., to Def. Couns. \& Other Pub. Def. Stakeholders 2 (July 1, 2019), http://www.ncids.org/ IndigentApptPlans/final $\% 20 \mathrm{memo}^{2} \% 20$ to $\% 20$ stakeholders $\% 207-1-19$.pdf [https://perma.cc/ 4JMN-3S4H].

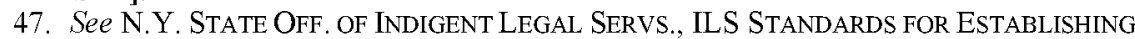
and AdMINISTERING Assigned CoUnSEl Programs: Black LeTter STANDARDS 12 (2019), https://www.ils.ny.gov/files/ACP/ACP\%20Black\%20Letter\%20Standards\%20070119.pdf [https://perma.cc/5GSF-5T2K].

48. See Ohio AppointMent of Couns. In CAP. CASes R. 4.01. 
these actors have shown interest in imposing such requirements on prosecutors. Perhaps the reason is that prosecutors have a powerful lobbying presence that would oppose statewide mandates. 49

The next part therefore considers whether trial judges would have a legal basis for imposing prosecutorial training requirements in the absence of legislative action.

\section{The Legal Basis for Trial Judges to Impose Minimum Training STANDARDS}

Can trial judges insist that prosecutors undergo training before being allowed to handle cases in their courtrooms? I will sketch both sides of the argument.

For courts that want to maintain the (unfortunate) status quo, there is a plausible argument that trial judges lack the authority to impose a training requirement on prosecutors. Trial courts do not set the standard for admission to the bar or the ethics standards with which lawyers must comply. ${ }^{50}$ In state court-where most criminal prosecutions occur-it is the state supreme court (typically through its designated board of bar examiners) that usually sets the rules for who is allowed to practice law. 51 Lawyers sometimes shoulder additional requirements, such as the criteria described in Part III for appointment to represent indigent defendants. But these additional requirements are usually imposed by state legislatures or their designees. In short, trial judges have never been imbued with the power to set additional qualifications for the practice of law. This argument is straightforward and would maintain the status quo.

A contrary argument can be imagined, however, by piecing together three traditionally separate areas of judicial authority: (1) the general inherent authority of courts, (2) judicial power to ban lawyers from courtrooms for misconduct, and (3) the power to deny pro hac vice motions.

\section{A. Inherent Authority}

Both federal and state courts regularly exercise inherent authority to regulate the lawyers who appear before them. 52 In doing so, judges

49. See Rachel E. Barkow, Administering Crime, 52 UCLA L. REV. 715, 728 (2005) (describing prosecutorial lobbying power).

50. An additional challenge would be making clear that requiring training before prosecutors can handle cases is not the same thing as disqualifying the entire district attorney's office. Federal courts have taken a very dim view of efforts to disqualify entire offices. See United States v. Bolden, 353 F.3d 870, 875 (10th Cir. 2003) ("[W]e can only rarely-if everimagine a scenario in which a district court could properly disqualify an entire United States Attorney's office.").

51. See Andrea A. Curcio, A Better Bar: Why and How the Existing Bar Exam Should Change, 81 NEB. L. REV. 363, 417-18 (2002).

52. See generally Fred C. Zacharias \& Bruce A. Green, Federal Court Authority to Regulate Lawyers: A Practice in Search of a Theory, 56 VAND. L. REV. 1303 (2003) (discussing inherent authority to regulate federal proceedings, the authority to admit and disbar lawyers, and intrinsic power to set standards governing professional conduct). 
sometimes impose obligations beyond what is codified in professional codes. ${ }^{33}$ In Chambers v. NASCO, Inc., ${ }^{54}$ the U.S. Supreme Court upheld a district court's decision to shift attorneys' fees to sanction bad faith litigation tactics.55 The Court explained that federal courts hold inherent power to, inter alia, control admission to the bar, punish contempt, and ban disruptive persons from the courtroom. ${ }^{56}$ That inherent power "can be invoked even if procedural rules exist which sanction the same conduct." 57 State courts have likewise claimed inherent power to regulate lawyers. 58

Courts' inherent power to regulate attorney conduct is not unlimited, of course. Legislatures can impose some statutory restrictions on courts' inherent power. Moreover, as two leading scholars have recognized, even absent statutory restrictions, "not all arguably wrongful conduct is sanctionable under the inherent authority." 59 Inherent authority should be limited to situations that threaten the judicial process, and sanctions imposed by courts should be proportionate to fall within inherent authority. 60 Moreover, not all regulations imposed by trial courts should be permissible under inherent authority. As Professors Fred C. Zacharias and Bruce A. Green recognized with respect to federal courts, it is easier to justify regulation "when it is directed at conduct that threatens the fair and efficient resolution of judicial proceedings." 61

A court rule requiring prosecutors to receive Brady training before being allowed to handle cases in the courtroom certainly aids the fair and efficient resolution of judicial proceedings. And such a rule is not a sanction for misconduct; it is the inverse - a prophylactic rule designed to avoid misconduct from occurring in the first place. To date, I am aware of no decision testing whether such a training rule would be permissible. But as discussed below, judges have exercised their authority to ban prosecutors and other lawyers from their courtrooms as a sanction for misconduct.

\section{B. Judges Can Ban Prosecutors for Individual Disciplinary Violations}

Although it does not happen very often, judges have occasionally banned lawyers from their courtrooms. These cases ordinarily happen when a judge believes (sometimes incorrectly) that a lawyer has engaged in misconduct. Litigation about the appropriateness of the ban sometimes ensues. Appellate

53. See Fred C. Zacharias \& Bruce A. Green, Rationalizing Judicial Regulation of Lawyers, 70 OHIO ST. L.J. 73, 83 (2009).

54. 501 U.S. 32 (1991).

55. Id. at $57-58$.

56. See id. at $43-44$.

57. See id. at 49.

58. Benjamin H. Barton, An Institutional Analysis of Lawyer Regulation: Who Should Control Lawyer Regulation-Courts, Legislatures, or the Market?, 37 GA. L. REV. 1167, 1243 n.285 (2003) ("Starting around the turn of the century, state supreme courts began to claim an inherent authority to regulate lawyers.").

59. See Zacharias \& Green, supra note 52, at 1344.

60. See id. at 1345-46.

61. Id. at 1348 . 
courts seem reluctant to wade into this thicket however and thus the legality of such bans is unclear. I highlight a few cases.

In 2014, the Texas Court of Criminal Appeals banned a highly accomplished defense attorney who handled pro bono capital cases from appearing before the court for one year. The Court of Criminal Appeals is the highest criminal court in Texas. Its stated reason for the ban was that the attorney had missed the deadline to file a motion for a stay of execution, in violation of the court's local rules. The one-year ban on appearing in the court resulted in considerable media coverage. ${ }^{62}$ The lawyer, as well as hundreds of other lawyers filing as amici curiae, argued that the Texas Court of Criminal Appeals lacked the authority to ban a lawyer from the courtroom because the Supreme Court of Texas has the exclusive authority to regulate the practice of law in the state.

The Supreme Court of Texas refused to intervene, noting that it lacked jurisdiction over the Texas Court of Criminal Appeals ${ }^{63}$ and that in any event, the criminal court was exercising disciplinary action over the lawyer, rather than setting the requirements to practice law. ${ }^{64}$

Another Texas case is perhaps more on point because it involves a judge banning a prosecutor from the courtroom. In Houston, a federal judge with a history of erratic behavior got upset with a federal prosecutor who had missed a pretrial discovery deadline.65 The judge made sexist comments about the prosecutor and then dismissed the charges against the defendant. The government successfully appealed the dismissal and the Fifth Circuit criticized the judge.66 A few months later, when that same prosecutor appeared before the trial judge on a different case, the judge excused her from a pretrial hearing and then asked her to leave a subsequent hearing a few days later. ${ }^{67}$ The U.S. attorney asked the Fifth Circuit to stay the case so that he could appeal the prosecutor's ejection, but the Fifth Circuit denied the stay. 68

Other courts have banned prosecutors from their courtrooms because of misconduct. For instance, a Pennsylvania trial court judge declared a mistrial in a firearm possession case because of a credible allegation that the prosecutor had threatened a witness. The judge then banned the prosecutor from her court:

I have been on the bench for 31 years. In that 31 years I have never once banned anyone from my courtroom.... However, Mr. Sachs, you are

62. See Terri Langford, Lawyer's One-Year Banishment Leads to Showdown, TEX. TRIB. (Mar. 27, 2015), https://www.texastribune.org/2015/03/27/1-year-lawyer-ban-heads-courtshowdown [https://perma.cc/5Z94-4D9X].

63. Texas has a bifurcated court system, with the Texas Court of Criminal Appeals being the highest criminal court.

64. See In re Dow, 481 S.W.3d 215, 223 (Tex. 2015). The idea that disciplinary action is somehow different than regulation of professional conduct is not particularly persuasive though. If a court can discipline a lawyer after he commits misconduct, it is not clear why the court cannot proactively impose training on a lawyer to prevent misconduct in the first place.

65. See Brief of Plaintiff-Appellant, supra note 12, at 4-5.

66. See United States v. Swenson, 894 F.3d 677, 681 n.3 (5th Cir. 2018).

67. See Banks \& Olsen, supra note 17.

68. See id. 
banned from my courtroom. I can no longer trust you. I find you to be sneaky. I find you to be able to backdoor people, and you're not allowed in my courtroom. 69

It does not appear that the district attorney's office challenged the ban, nor that the judge otherwise retracted her ruling. ${ }^{70}$

In addition to banning prosecutors, some judges have ordered prosecutors to undergo training. The best-known case arose from the Deferred Action for Childhood Arrivals litigation in a federal court in Brownsville, Texas. The judge believed that prosecutors had lied to the court about when deportation delays would go into effect. In response, the court ordered thousands of lawyers from the U.S. Department of Justice (almost none of whom were involved in the litigation) to attend a legal ethics course taught by an independent expert.71 The Justice Department contested the order and the judge eventually backed down and withdrew the training requirement. 72 More recently, a federal judge in the Southern District of New York became incensed when federal prosecutors belatedly turned over favorable evidence and attempted to bury it in the middle of other documents. The judge "ordered every federal prosecutor in Manhattan to read her decision criticizing the prosecution failures."73

In sum, there are examples of trial judges imposing courtroom bans, but there are very few appellate decisions on the legality of such bans. As described below, there is clearer and more robust authority with respect to prohibiting lawyers from other jurisdictions from appearing pro hac vice.

\section{Pro Hac Vice Motions and Trial Judges as Gatekeepers}

When clients hire out-of-state lawyers to represent them, the lawyers must file pro hac vice motions so that they can appear in courts where they are not admitted to practice. Normally, such motions are simply a formality and are almost always granted. ${ }^{74}$ Courts do have power to reject pro hac vice motions though, when the lawyers have a history of ethics violations, the

69. Commonwealth v. Byrd, 209 A.3d 351, 359 (Pa. Super. Ct. 2019).

70. See Email from Frank Walker, Couns. for the Def., to author (June 23, 2020) (on file with author).

71. See Memorandum Opinion \& Order at 24-25, Texas v. United States, No. 14-cv00254 (S.D. Tex. May 19, 2016).

72. See Memorandum Opinion \& Order at 2, 19, Texas, No. 14-cv-00254 (S.D. Tex. Jan. 19, 2017).

73. Debra Cassens Weiss, Incensed Judge Orders Every Federal Prosecutor in Manhattan to Read Her Decision, ABA J. (Sept. 17, 2020), https://www.abajournal.com/ news/article/incensed-judge-orders-every-federal-prosecutor-in-manhattan-to-read-herdecision [https://perma.cc/M8VW-NYTM]

74. See Kampitch v. Lach, 405 F. Supp. 2d 210, 215 (D.R.I. 2005) ("Generally, motions for pro hac vice admission are granted as a matter of course."); Kohlmayer v. Nat'1 R.R. Passenger Corp., 124 F. Supp. 2d 877, 880 (D.N.J. 2000) (describing a "trend of leniently granting pro hac vice admission"). 
lawyers would frustrate the litigation process, they appear not to understand the jurisdiction's rules, or attorneys appear to be generally uncivil. 75

For instance, a federal district court denied pro hac vice admission to a lawyer who had seemingly lied about being denied pro hac vice status in the past and who incorrectly represented that he had not been sanctioned in the past. The court explained that " $[\mathrm{w}]$ hen forewarned with a substantial amount of evidence that an attorney is likely to hinder the litigation process, a court should not and cannot be forced to grant a pro hac vice application of that attorney."76 Other courts have similarly recognized that pro hac vice admission can be denied even when there was no official disciplinary action in the state where the lawyer is barred. 77

Judges have also denied pro hac vice motions when it appeared the lawyers did not understand the court's local rules. In a case in the Southern District of New York, a lawyer filed a substantive motion before filing the pro hac vice motion to be admitted in the first place. The court concluded that by submitting the substantive motion, the lawyer may have engaged in unauthorized practice of law. In denying the pro hac vice motion, the court explained that

this Court must have some reasonable assurance that such attorney is familiar with the Federal Rules of Civil Procedure, the Local Rules for the Southern District of New York, this Court's Individual Rules, and the customs and practices of this Court. In light of the actions that plaintiffs' counsel has taken in the instant litigation to date, this Court lacks such a reasonable assurance. 78

The court also explained that "[ $t]$ he interests of judicial economy militate against permitting attorneys who are not competent to practice before this Court to appear pro hac vice." 79

In addition to denying pro hac vice admission for lying, ethics violations, and misunderstanding of local rules, courts have also rejected admission for general incivility. For instance, a federal judge in New Jersey pointed to a lawyer's poor courtroom behavior and general incivility (for instance calling opposing counsel a "fat pig" four times) in denying admission. The judge explained that "[c]ourts can use their discretion to deny the privilege of pro hac vice admission to attorneys who consistently act in an uncivilized

75. See Michael A. DiSabatino, Annotation, Attorney's Right to Appeal Pro Hac Vice in State Court, 20 A.L.R. 4th 855 (1983). Courts can also revoke pro hac vice status, although to do so typically requires that the lawyer have violated an ethics rule. See, e.g., United States v. Nolen, 472 F. 3d 362, 375 (5th Cir. 2006) ("We agree with the Eleventh Circuit that once a district court has admitted an attorney to practice before it pro hac vice, it may revoke that attorney's admission if, after following the proper disciplinary procedure, it concludes that the attorney violated a clearly identifiable ethical rule.")

76. Kampitch, 405 F. Supp. 2d at 218 (quoting Kohlmayer, 124 F. Supp. 2d at 882).

77. See Bundy v. State, 455 So. $2 d$ 330, 348 (Fla. 1984) ("[C]ourts of this state are not bound by the lack of disciplinary action in other states in determining whether an attorney should be admitted to the bar pro hac vice.").

78. Erbacci, Cerone \& Moriarty, Ltd. v. United States, 923 F. Supp. 482, 485-86 (S.D.N.Y. 1996).

79. See id. at 486 . 
manner, regardless of whether formal ethical complaints have been made against the pro hac vice applicant." 80

Of course, the pro hac vice cases are not a perfect precedent for concluding that trial judges have the power to demand that prosecutors complete prosecutorial misconduct training before being able to handle cases in their courtrooms. The reason is that prosecutors are already admitted to the bar and any further obligations imposed by trial judges would seemingly exceed the statewide rules for practicing law. Put differently, there is a difference between judges carefully vetting lawyers who are seeking permission to appear from out of state and screening lawyers who are already licensed in that jurisdiction.

At the same time however, the pro hac vice cases provide a useful analogy for trial judges' power to impose mandatory prosecutor training. The pro hac vice cases tell us that trial judges are the gatekeepers of the courtroom. The trial judges are supposed to take steps that will prevent future ethics violations, incivility, and rule violations. As the Ninth Circuit has explained with respect to defendants' choice of counsel:

"A defendant's right to the counsel of his choice includes the right to have an out-of-state lawyer admitted pro hac vice." However, the Sixth Amendment right to chosen counsel is not absolute; it can be abrogated to serve a "compelling purpose." Ensuring the ethical and orderly administration of justice is one such purpose.$^{81}$

Similarly, as one court explained in revoking a defense attorney's pro hac vice status, the court must balance a defendant's "constitutional right to retain counsel of his choice 'against the need to maintain the highest standards of professional responsibility, the public's confidence in the integrity of the judicial process and the orderly administration of justice."'82

Imposing training obligations on prosecutors serves to ensure the ethical and orderly administration of justice. Prosecutors who are specifically trained to avoid Brady, Batson, and other types of prosecutorial misconduct are less likely to violate the rights of criminal defendants and thus less likely to undermine justice.

Moreover, requiring that prosecutors undertake training before handling cases in a courtroom is a minor imposition in comparison to the possible benefits of such training. While training may save a defendant from being unjustly convicted, the cost to the district attorney's office is only a few hours of time to update prosecutors' legal education. By way of comparison, imposing a training mandate is far less of an imposition on prosecutors than

80. Kohlmayer v. Nat'1 R.R. Passenger Corp., 124 F. Supp. 2d 877, 883 (D.N.J. 2000) (citing additional cases)

81. United States v. Ries, 100 F.3d 1469, 1471 (9th Cir. 1996) (citations omitted) (first quoting United States v. Lillie, 989 F.2d 1054, 1056 (9th Cir. 1993; and then quoting United States v. D'Amore, 56 F.3d 1202, 1204 (9th Cir. 1995)).

82. United States v. Howell, 936 F. Supp. 767, 773 (D. Kan. 1996) (quoting United States v. Collins, 920 F.2d 619, 626 (10th Cir. 1990)). 
rejecting a pro hac vice motion and denying a defendant the attorney of his choice.

\section{CONCLUSION}

Scholars and reformers typically turn to ethics codes, disciplinary bodies, and appellate courts to deal with the problem of prosecutorial misconduct. Trial judges have played a minimal role. In rethinking regulation of lawyers and the role of courts, we should place more power and faith in the hands of trial judges.

Historically, trial judges have played no role in determining which prosecutors are assigned to their courtrooms and how much training those prosecutors receive to avoid misconduct. In medium-sized and large jurisdictions, a single judge can begin to change the status quo though. By requiring prosecutors to complete adequate training in prosecutorial misconduct before allowing them to handle cases in their courtrooms, judges can initiate a race to the top. In an effort to avoid losing better-trained prosecutors, other judges will follow the first mover and demand the same or better training for prosecutors in their courtrooms. District attorneys' offices will be forced to provide better training to their prosecutors, which in turn should reduce accidental prosecutorial misconduct.

To be clear, the legal basis for trial judges imposing a training prerequisite is debatable. On the one hand, we should be reluctant to let judges burden lawyers' ability to practice law, especially when the attorneys have otherwise satisfied the jurisdiction's rules for admission to practice. On the other hand, the burden on prosecutors to complete the required training would be minimal. And trial judges do exercise inherent authority in comparable situations, such as ruling on pro hac vice motions and banning lawyers from their courtrooms when exercising their disciplinary authority.

While the legality of trial judges' power to insist on training prerequisites might be debatable, forward-thinking courts should find a way to uphold it. The traditional modes of dealing with prosecutorial misconduct-ethics codes, disciplinary bodies, public shaming, and reversing convictions-have not worked. If we want to rethink the role of courts in regulating lawyers, we should put more faith and power in the hands of the judges on the front lines who deal with prosecutors and prosecutorial misconduct most often. 